\title{
Potřebujeme environmentální etiku?
}

\section{Pavel Skála}

Envigogika 2007/II/1 - Recenzované články/ Reviewed Papers

Publikováno/Published 16. 04. 2007

DOI: http://dx.doi.org/10.14712/18023061.15

\section{Abstrakt:}

Článek se pokouší upozornit na všeobecnou teoretickou nezakotvenost a nepodloženost mainstreamu současné environmentální etiky a z nich vyplývající rizika, a nastínit povahu možných teoretických základů, na nichž by environmentální etika mohla být prípadně rekonstruována.

\section{Klíčová slova:}

Etika, environmentalizmus, environmentální etika, ekologická etika, hodnoty, environmentální výchova, ekologická výchova, environmentální vzdělávání, morální ekologie, hlubinná ekologie, ekopsychologie

\section{Abstract:}

The paper argues some traditional concepts of environmental ethics. It describes it as a complex effort to sustain the moral values of human society (Polis) in the relation to the totally different (amoral) entirety of the nature of the universe (Physis).

\section{Key words:}

Ethics, environmentalism, environmental ethics, ecological ethics, values, environmental education, moral ecology, deep ecology, ecopsychology 
Ekologická či přesněji environmentální etika je běžně (alespoň v environmentalistických kruzích) chápána (Kol., 2001) jako podoblast jakési "obecné" etiky, vztažená k životnímu prostředí člověka, at' už jde o zájmy člověka $v$ tomto jeho prostředí, nebo $v$ nějakém smyslu o zájmy tohoto prostředí samotného. Lze však snadno ukázat (srov. př́klady níže), že - a to nejen v environmentalistických kruzích, právě zde je to však i kvůli výše uvedené skutečnosti poněkud alarmující - právě onen pojem etiky „obecné"/,samotné"/ „jako takové" je dnes v naší společnosti jednak dosti nejasný (což je níže ještě dále rozvedeno), jednak však - a to se mi zdá být ještě horší - v této jeho nejasnosti převládá takové jeho tápavé chápání (byt' většinou neuvědomované - to však nikterak nesnižuje jeho praktické důsledky, spíše naopak...), které představuje značný posun - a z mnoha hledisek by se navíc dalo hovořit o deformaci, a to deformaci "nejtěžšího kalibru" - původního určení etiky, zakotveného v antice (nejpưvodněji zřejmě u Aristotela v Etice Níkomachově), a to posun, který by mohl mít poměrně dosti neblahé důsledky pro společenskou praxi.

Oním tradičním určením etiky bylo její iniciování/chápání jako určitého filosofického zkoumání normativity: zhruba řečeno, toho, čím by mělo být řízeno lidské jednání (Ize-li je, ovšem, řídit...), k čemu by mělo směřovat, jaké je správné jednání (Anzenbacher, 1991, s. 45 a s. 47). Současná „speciální" (nejen ekologická/environmentální, ale třeba i lékařská, právní, obchodní atd.) etika, však, zdá se, na tento pưvodní filosofický kontext většinou ve velké míře zapomíná. To je však tedy, obávám se, společensky alespoň potenciálně značně nebezpečné. Onen filosofický kontext totiž např. předpokládá, že než řekneme, jaké jednání je ( $v$ jaké situaci) správné, máme již nějakou dobře zdůvodněnou představu toho, co je správné - správnosti samé (resp. známe rovněž relevantní charakteristiky oné situace nebo dokonce relevantní charakteristiky společné všem myslitelným situacím...); že tedy také než řekneme, čím by mělo být lidské jednání řízeno, máme dobré důvody tvrdit, že je skutečně řídit lze, jinak řečeno, že se vủbec jedná o „subjektivně" ovlivnitelné jednání, a ne pouhé (prostředím, at' už tím $v$ běžném slova smyslu "vnějším" nebo tím "vnitřním", např. nějakými geny či podobnými předpokládanými jsoucny...) přísně determinované chování [tento problém je zřejmě problémem smysluplnosti (obecné) etiky vůbec - tentokrát tváří $v$ tvář myšlení mainstreamu současné biologie]. Bez "ošetření" všech těchto (a jistě mnohých dalších) předpokladů - které však zřejmě obnáší neustálý dialog s příslušnými jinými "oblastmi" či "směry" filosofického zkoumání - se totiž etika mění v pouhé dogmatické a nepodložené moralizování, které nejenže je iracionální a, z triviálních psychologických důvodů, samo o sobě společensky (tzn. i/především v rámci environmentální výchovy a vzdělávání!) neúčinné (protože nemotivující, alespoň ne pozitivně a specificky), ale (možná nejen) $v$ rukou autoritářského establishmentu se naopak může stát i velice agresivní ideologií vedenou v duchu „my víme, co je správné, a to i pro tebe (tím je myšlen kterýkoliv člen dotyčné společnosti, resp. vůbec člověk, příp. jiná bytost), a jsme oprávněni tě $k$ tomu přimět třeba i proti tvé vůli, zvláště když se nás na tom dohodla většina" - kteréžto stanovisko je zřejmě základem mnoha totalitních režimů...

Domnívám se, že je v nejvlastnějším zájmu environmentalismu, aby se takovémuto či podobnému potenciálně diskreditujícímu vývoji vyhnul a přestal formulovat podobné „etiky"; ostatně, bylo jich už vymyšleno až dost (srov. např. ty v Erazimem Kohákem a kol. redigovaném sborníku Závod s časem, 1996); drtivá většina z nich staví na nějakém axiomu, nepodloženém, ba většinou ani neuvědomovaném předpokladu (to ovšem neznamená, že tento nemůže být v nějakém smyslu pravdivý - filosofické založení etiky tu však požaduje nějaké racionální zdưvodnění této pravdivosti - má-li si tedy, ovšem, environmentální etika činit nárok na pozici určitého speciálního odvětví etiky obecné). Tak např́klad Albert Schweitzer (jakkoli jinak jistě úctyhodná postava) bez jakékoli podpưrné argumentace prohlašuje, že nejvyšší hodnotou je život a úcta k němu, což nejen neodůvodňuje, ale ani nevymezuje, co zde vlastně myslí životem, úctou a hodnotou. Aldo Leopold či J. Baird Callicott, stejně jako jinak radikální hnutí typu Earth First!, podobně nereflektovaně za nejvyšší hodnotu vydávají přírodu, řekněme ve smyslu víceméně aktuálního (v Callicottově době ještě relativně stabilního) stavu biosféry, Annie Dillard blíže nespecifikovanou lásku, nesenou dle předpokladu jedině lidstvím, Arne Naess rovněž 
důsledně nevymezené harmonické soužití všech bytostí a kvalitu života, Kristin S. ShraderFrechette dobrovolnou skromnost, sociální spravedlnost a morální vyrovnanost, Gary Snyder (sebe)poznání a z něj vyplývající odpovědnost, Michael Pollan nepokrytě antropocentrickou, "zahradnicky" opečovanou harmonii s prírodou, Henryk Skolimowski opět život - což zdůvodňuje předpokládanou, ale opět nedoloženou, biologicky-druhově specifickou lidskou morálkou a odpovědností - dále pak stř́dmost, diverzitu a spravedlnost... (vše ibid.). To, jak všichni tito autoři své předpoklady rozvíjejí, je bezpochyby zajímavé, inspirativní, společensky významné a leckdy jistě i svým způsobem hluboké, přesto však ani to nezapadá do filosofického žánru etiky.

Zatím jedinou environmentální etikou, se kterou jsem se setkal (což ovšem samozřejmě není nikterak obecně směrodatné), která nějaké zdůvodnění nabízí, je (paradoxně?) ta prezentovaná $v$ práci právě Erazima Koháka Oheň a hvězdy (nedat.). Ačkoliv je však autor jinak zřejmě vynikající filosof a navíc fenomenolog, jeho argumentace zde se mi jeví jako nejen nefenomenologická, ale i jako nefilosofická: nepřekračuje - $v$ podstatě deklarovaně - rámec mystiky, byt' nepochybně autentické. Mystika je jistě rozměr podstatný nejen pro život jako celek, ale i speciálně pro filosofii; to, že múže být její animou, ji s ní však ještě neztotožňuje. Nejenže jde o zkušenost $v$ podstatě nevykazatelnou, ale (navíc) je to zkušenost „intersubjektivně" nepřenosná a (tudíž) už vůbec nijak spolehlivě použitelná $v$ jakékoliv společenské praxi $(m j$. zvláště té pedagogické). (Autor sice vypráví, za jakých okolností jeho mystická zkušenost nastala, nepodává však nic, co by blíže poukazovalo na relevanci (ve smyslu konstitutivnosti) právě těchto okolností pro vznik oné zkušenosti; zřejmě protože pro tuto relevanci nemá - a asi ani, z dưvodu obecné povahy mystické zkušenosti, nemůže mít - žádné měřítko, žádný indikátor...)

Po těchto úvahách se tu nabízí otázka: jak, na čem tedy založit environmentální etiku? Anebo: proč ji vlastně vůbec zakládat/dělat? Ani ona dosavadní environmentální etika (snad jen kromě té nejpokleslejší, v nejméně dvojitých uvozovkách, která je však, žel, zřejmě nejčastěji provozována ve vzdělávací praxi) se nezabývá tím, jak konkrétně jednat $\vee$ prostředí, aby se toto neničilo (resp. aby se neničila jeho schopnost podporovat život člověka - tj. např. nehromadit, neplýtvat, recyklovat atd.); tím se zabývají víceméně technické disciplíny, které vlastně zkoumají, co je třeba (ne)dělat pro to, abychom (si) životní prostředí neničili. Tím, na co se většinou snaží odpovídat environmentální etika, je hlavně otázka, proč bychom (si) vlastně životní prostředí neměli (z)ničit: a odpovědí je vždy nějaká hodnota (na jejímž základě Ize teprve - je-li to ovšem vůbec možné - alespoň nějak smys/uplně řídit vlastní chování, i využívat oněch technických poznatků), která pak často zakládá různé "centrizmy" (biocentrizmus, ekocentrismus atp.). Jedním z problémů této odpovědi (jakožto odpovědi etické), domnívám se, je právě to, že není konkrétní, ani z ničeho konkrétního vyvozená, nýbrž abstraktní, ve smyslu nesouvislosti s (i v př́padě oné již zmíněné, příp. nějaké podobné mystiky) nějak racionálními prostředky uchopitelnou konkrétní zkušeností.

Proč vlastně byla nějaká etika vůbec „vyvíjena"? Patrně proto, že začala panovat určitá nejistota ohledně toho, jak jednat, $a-v$ př́padě výskytu nějaké odpovědi na tuto otázku - proč právě tak... I když budeme předpokládat, že (svobodné) jednání je možné, Ize si jen těžko představit, že na obecně etickou otázku je možné nalézt nějakou definitivní odpověd'. Na onu druhou otázku "proč právě tak?” totiž může být odpovědí zřejmě vždy opět jedině nějaká hodnota, a ta je ze své povahy nevykazatelná, nebot' hodnocení, jak výslovně ukázal např. Carl Gustav Jung (1996), je, lapidárně řečeno, věcí citu, nikoliv rozumu. Etici původně (od svého "otce" Aristotela) odvozují mravní hodnoty z nějaké předpokládané povahy "esence"/,podstaty" člověka (Anzenbacher, 1991, s. 240) ${ }^{1}$ a ukazují, že takovéto hodnoty Ize smysluplně odvozovat od určitých hypotetických

${ }^{1} \mathrm{~V}$ současnosti se o to, zdá se mi, velmi specificky a navíc z environmentalistické pozice, pokouší např. Andy Fisher (2002, s. 107). 
(elementárních) potřeb člověka daných jeho přirozeností; ovšem ani tyto potřeby zdaleka nejsou plně racionálně vykazatelné2.

Zdá se mi, že v tomto bodě je užitečné (právě abychom se vrátili ke konkrétnosti) přejít ke specifikům právě nějaké té „speciální", v našem případě environmentální etiky. Přiznejme si otevřeně, že je to cosi, co vzniklo především v zájmu "nás environmentalistư" (ve smyslu příslušnosti primárně $k$ environmentalismu jako společenskému hnutí, nikoli $k$ environmentalistice jako vědě), at́ už $s$ jakýmkoliv backgroundem. A nám, environmentalistům (a možná právě tím jsme jako environmentalisté vůbec vymezeni) jde zřejmě především o to, aby současnou environmentální krizi přežilo bez úhony lidstvo, resp. mimolidské prostředí, resp. biosféra, resp. život atp. (někdy: přibližně v tom stavu, v jakém se nacházejí nyní, alespoň fyzickém...). Když pomineme, že vůbec není zcela jasno v tom, co to znamená "přežít", "bez úhony" či ona "identita stavu", nedobereme se zřejmě - my ani nikdo jiný - nikdy toho, zda je toto naše přání "správné" či nikoli - ono totiž podle všeho není - jak se takového potvrzení dobrat v oblasti racionálně vykazatelného.

Jistě je důležité, a osobně si myslím, že - v zájmu "věci" - dokonce nutné, kontinuálně pokorně zkoumat vlastní motivaci. To je však, jak ukazuje celá dlouhá tradice dynamické psychologie, potenciálně prakticky nekonečný proces (protože i jestliže „existují" nějaké „poslední či „základní" potřeby, „cesta k nim" může vést přes nekonečně velký - nebo alespoň z principu nezjistitelný - počet oklik). Nejistota vlastní motivace však není důvodem $\mathrm{k}$ rezignaci na jakékoliv jednání (je-li tedy nějaké jednání v pravém/úzkém slova smyslu vůbec možné...).

Myslím, že určitým řešením je zde přesunutí celého environmentálního problému do sféry politické, ovšem, $v$ nejširším možném slova smyslu (klasická, dnes zčásti již praktikovaná „zelená politika" je jistě krajně problematická, ne-li prímo environmentalisticky kontraproduktivní...): jde tedy o to, že „my environmentalisté", jako jedna ze skupin společnosti, („momentálně") „vyznáváme" určité hodnoty, a máme z nich vyplývající zájmy (jakkoliv tyto hodnoty třeba při tom kontinuálně zkoumáme a případně modifikujeme), stejně jako jiné společenské skupiny, které mají zase své, v nějakém smyslu někdy jiné hodnoty a zájmy. Žel, hodnoty a zájmy jednotlivých společenských skupin jsou často $v$ konfliktu (přinejmenším z některých hledisek). Jakkoli kriticky tedy budeme zkoumat své vlastní hodnoty, tak dokud nedojdeme k jejich zpochybnění, má jistě smysl se podle nich řídit a prosazovat je (protože jinak asi není, podle čeho se smysluplně rídit...).

Toto prosazování by ale rozhodně nemělo být manipulativní. I když opomineme morální - a etickou ${ }^{3}$ - problematičnost manipulace, je to opět dynamická psychologie, která nám ukazuje jednak, že manipulativní techniky nikdy nepronikají do hloubek motivačních "struktur", a jsou tak tedy z dlouhodobého hlediska neefektivní, jednak, že se manipulace - vyznačující se tím, že vždy více či méně obchází vědomí - vystavuje riziku, že vyvolá úplně jiné chování, než které vyvolat zamýšlela. Mám vážné obavy, že naprostá většina dosavadní environmentální etiky je ve skutečnosti, spíše než etikou, právě jen oním moralizováním, psychologicky $v$ praxi více či méně pưsobícím manipulativně (at' už záměrně či nikoliv) prostřednictvím vyvolávání pocitů viny, strachu, různými autoritativními figurami, indoktrinací apod. ${ }^{4}$

${ }^{2}$ O jednoznačné a logické dokazatelnosti ani nemluvě, ale ta je zřejmě zcela nemožná obecně, právě už i jen z téměř čistě logických důvodů, což již více než naznačil např. Paul Karl Feyerabend (2000).

${ }^{3}$ Tradiční terminologický rozdíl spočivá v tom, že moralita jednání znamená jeho shodu se svědomím, zatímco etičnost či mravnost se týká obsahu jednání nezávisle na svědomí (Anzenbacher, 199, s. 223).

${ }^{4}$ Podobně jako většina dosavadní environmentální výchovy, jak o tom mluví např. Theodore Roszak (1993). 
Jak ale postupovat nemanipulativně? $\mathrm{K}$ tomu je asi dobré zopakovat si, o co nám vlastně jde: především asi chceme, aby (nejen) nám ostatní lidé svým jednáním už neničili životní prostředí (pro nás alespoň "dostatečně dobré", jak by řekl Donald Woods Winnicott...). Nejefektivnější cestou k tomu je patrně zcela otevřené pưsobení na jejich motivaci v tom smyslu, aby její výsledná - a to zásadně vědomá - "konfigurace" indukovala chování prostředí nepoškozující; tomuto kritériu zřejmě nejlépe vyhovují "metody" (psycho)analytické - na nenáležité interpretace „analyzand" jednoduše „neslyší". To ovšem předpokládá nějaký relevantní a dostatečný - a co to ovšem znamená? - stupeň poznání jednak obecné "struktury" a "dynamiky" lidské motivace (Ize-li co takového ovšem nalézt, čemuž však mnohé nasvědčuje, mj. ve společenské praxi relativně úspěšná tradice motivační a vývojové psychologie), jednak momentů chování, které životní prostředí poškozuji (a co toto znamená?), jejich vlastní dynamiky (včetně její ontogeneze - to může poskytnout významný teoretický základ pro pedagogické působení - př́íp. i fylogeneze), a nakonec zpưsobů, jak na (vývoj) motivační struktury působit ve výše uvedeném smyslu.

Nemanipulativní charakter dynamicko-psychoterapeutických "metod" s sebou, ovšem, nese riziko neefektivnosti, ba až naprosté neúčinnosti: analytická technika je schopna přivést $v$ lidech ku vědomí jen ty obsahy (jako např. motivace), které $v$ nich již jsou nějak - nevědomě - přítomny. Není-li tedy člověk nějak od přirozenosti schopen žít v harmonii se svým prostředím (což nepřímo naznačují např. mainstreamoví biologisté, hlavně sociobiologové, avšak psychologové - oproti biologům spíše ve fenomenologickém než objektivistickém rámci - naopak vyvracejí), pak jsou tyto postupy k ničemu. Momentálně si však jinou smysluplnou (tj. mj. alespoň nějak kontrolovatelnou a potenciálně produktivní) cestu pro environmentální pedagogiku nejsem schopen představit.

Zde se, zdá se mi, otevírá prostor pro celou novou oblast bádání, kterou již zčásti pokrývá ekopsychologie, mladý směr dynamické psychologie založený již zmíněným Theodorem Roszakem (1993; 1995), který se již určitým způsobem diversifikoval (International Community for Ecopsychology, 2004-; Fisher 2002) ${ }^{5}$ Ukazuje se však, že především jeho metodologické základy zatím ještě nejsou příliš koherentní a vykazují mnohé problémy (srov. např. Skála, 2003), na jejichž odstranění by se mohl orientovat další výzkum.

$\mathrm{Na}$ závěr je asi třeba vrátit se k problému "užitečnosti" environmentální etiky. Na základě výše uvedených dưvodů se domnívám, že environmentální etika sama o sobě je přinejmenším v posledku zcela neefektivním environmentalistickým nástrojem (pokud ne tedy přímo kontraproduktivním). Viděl bych však její smysluplnost, pokud by byla pojata jako určité vědomé hledání, reflexe ( $a$ "vydávání počtu z" - ve smyslu smysluplné racionální řeči) určitých „pravidel" našeho harmonického soužití s naším životním prostředím (tj. soužití $v$ souladu $s$ jeho i našimi relevantními potřebami - co to ovšem znamená, není opět nikterak triviální otázka), ovšem tak, jak se nám tato „pravidla” (spíše asi jen ustálené zpưsoby) - a jejich opodstatnění - prưběžně, a přirozeně proměnlivě dávají ve zkušenosti (nikoliv ve spekulativní odtrženosti od ní). Archaickou variantou toho jsou možná mýty o tom, proč se "co má dělat tak a tak", "vysvětlující" např. všemožná tabu, úkolem etiky jako filosofické „disciplíny" je možná odstranit z tohoto "vysvětlování" uvozovky...

\footnotetext{
5 Ekopsychologii jako celek by snad pro naše potřeby bylo možné charakterizovat jako snahu porozumět psychologii vztahu člověka s jeho prostředím, především těm podobám tohoto vztahu, které mají vliv na další vzájemnou koexistenci lidské populace a jejího přírodního prostředí. Z tohoto hlediska jde, dle mého názoru, hlavně o výzkum dynamiky vztahu k prostředí, zejména záležitostí motivace a její ontogeneze, především té nějak typické pro naši civilizaci. Ve svých dynamických formách představuje ekopsychologicky orientovaná psychoterapie proces, $v$ němž se, podobně jako $v$ jiných směrech dynamické psychoterapie, dialekticky střídají výzkum a terapeutické testování jeho výsledků. $Z$ poznatků se zde tedy nestávají žádné nehybné axiomy, na nichž by se dále jen cosi stavělo, nýbrž jsou neustále konfrontovány s další praxí.
} 


\section{Literatura}

- $\quad$ Anzenbacher, A. (1990). Úvod do filozofie. Praha: SPN.

- Ecopsychology on-line [online] (1998). : The Ecopsychology institute. Retrieved from http://ecopsychology.athabascau.ca

- $\quad$ Feyerabend, P. K. (2001). Rozprava proti metodě. Praha: Aurora.

- Andy, F. (2002). Radical ecopsychology : Psychology in the service of life.. Albany (NY): State University of New York Press.

- International Community for Ecopsychology [online] (2004). .

- Gustav, J. C. (1993). Analytická psychologie : Její teorie a praxe.. Praha: Academia.

- Kohák, E. . Oheň a hvězdy : Filosofické hledání mravního smyslu př́rody. Autorizovaný český překlad v samizdatu (bližší bibliografické údaje neznámé). .

- Kohák, E., \& Kolářský, Rudolf, Míchal, Igor (eds.), (1996). Závod s časem : Texty z morální ekologie. Praha: Ministerstvo životního prostředí.

- Kol. Diderot : Velká všeobecná encyklopedie (2001). Praha: Diderot.

- Theodore, R. (1993). The voice of the Earth. London, New York, Toronto, Sidney, Auckland: Bantam press.

- Theodore, R., KANNER Allen D., , \& GOMES, Mary, E., (1995). Ecopsychology : Restoring the Earth healing the mind. San Francisco (CA): Sierra Club Books.

- Skála, P. (2003). Pojetí (duševního) zdraví v tradici moderní psychologie $v$ konfrontaci $s$ fenoménem ekologické krize a teorie roszakovské ekopsychologie (Diplomová práce - Mgr.). Praha: Univerzita Karlova v Praze, Fakulta humanitních studií, Katedra obecné antropologie.

\section{Recenzní posudky (slovní hodnocení příspěvku)}

\section{Recenzent 1:}

Tomáš Daněk - Fakulta humanitních studií UK, Ústav mezioborových studií ZČU, Fakulta sociálních studií MU

"Autor dostál předsevzatému tématu zejm. upozorněním na skutečnost, že z vágnosti pozice současné etiky jako takové vyplývá problematičnost i etiky ekologické, jakožto disciplíny odvozené, skýtající ideové zázemí ekologického myšlení a konání.

Za nejsilnější myšlenky považuji: upozornění na vágnost, ba až bezmocnost současné argumentace vedené $z$ pozic at́ už jakékoli etiky $v$ porovnání $k$ síle mainstreamových výkladových konceptů, zejména biologických a dále upozornění na skrytý potenciál často nereflektovaných východisek ekologické etiky sklouznout do pozice garanta totalitním, agresivně ideologickým politickým praktikám. V celku názorné je také ozřejmění autorem kritizovaných, nereflektovaných východisek v článku zmiňovaných typů ekologické etiky ve vztahu k maximě obecné etiky racionálně zkoumat a reflektovat svá vlastní východiska.

Za symptomatickou pro současnost považuji autorem zmíněnou alternativu učinit environmentální problémy ,pouhým' předmětem jisté zájmové politické skupiny, který vnímám jako rezignaci na jejich reálné projevy.

Za problematické považuji: 
1. Místy nejasné vymezení kritiky etiky ekologické ve vztahu k etice obecné na straně jedné a kritiky etiky obecné ve vztahu k prírodovědeckým interpretacím světa na straně druhé.

2. Jasnou artikulaci nároku, který autor na ekologickou etiku klade. Z textu není zřejmé, zda je kritika míněna jako spíše metodologická (axiomy ekologické etiky jsou nedostatečně racionálně zdůvodněny, což je podle autora pro etiku jako takovou stěžejní) či fundamentální (ekologické etiky - at' už jakkoli, tedy ne nutně racionálně, ale nereflektují svá východiska).

Byt́ autor $v$ závěru nabízí možnost rehabilitace významu ekologické etiky jakožto , vědomého hledání, reflexe (a ,vydávání počtu z') určitých ,pravidel' našeho harmonického soužití s naším životním prostředím', není jasně řečeno, jakým způsobem by měl být tento počet vydán (viz body 1 ) a 2)).

Ve vztahu $k$ výše uvedenému nevyznívá př́liš přesvědčivě ani domněnka, že by ,nazrál čas' pro ekopsychologii, kterou autor nabízí jako možné, byt́ blížeji nepopsané východisko.

S uvedenými výhradami považuji článek za standardní pro časopisy typu EnviGogika, tematizuje současnou problematiku $v$ oblasti environmentální etiky a přináši další, pozoruhodný pohled na ni."

\section{Recenzent 2:}

Pavla Koucká - Katedra filozofie a dějin prírodních věd Prírodovědecké fakulty UK

„Text přináší důležité upozornění na fakt častého zaměňování etiky a moralizování. S leckterými sděleními a názory autora by bylo možné polemizovat (např́klad pokleslost environmentální etiky ve vzdělávací praxi či vhodnost přesunu environmentalistickovýchovné problematiky z oblasti etiky do oblasti politiky a dynamicko-psychologicky založené psychoterapie). Ale to není špatně, možná dokonce naopak. Rozpoutat diskuzi na toto téma by bylo fajn." 
Časopis Envigogika vydává Centrum pro otázky životního prostředí UK. Vývoj časopisu je podpořen projektem OP VK Mezioborová sít udržitelného rozvoje.

Více najdete na internetových stránkách projektu mosur.czp.cuni.cz
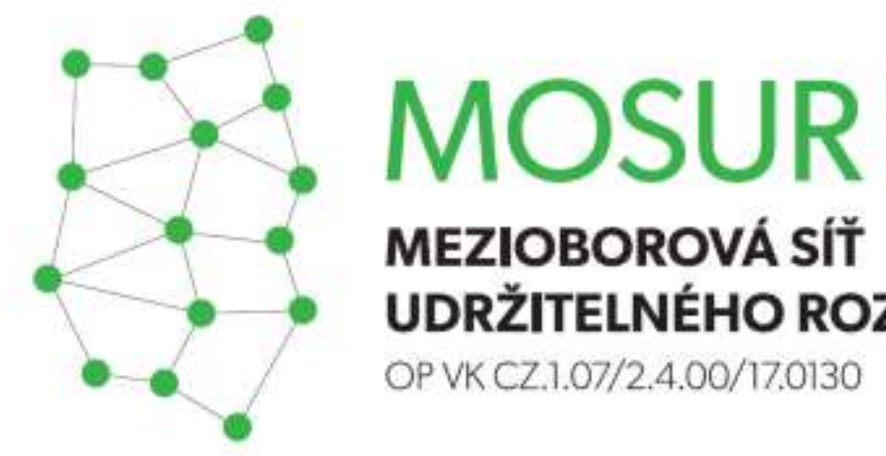

\section{MEZIOBOROVÁ SÍT} UDRŽITELNÉHO ROZVOJE

OP VK CZ.1.07/2.4.00/17.0130
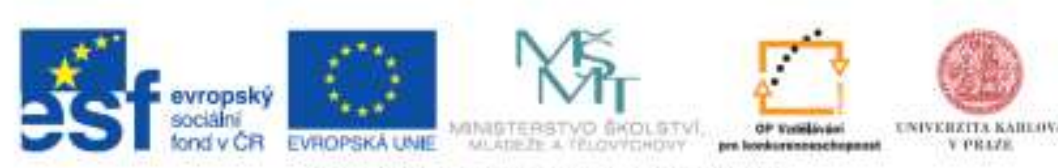

INVESTICE DO ROZVOUE VZDELAVANI 